\title{
De Crowdfundingverordening, a brand new beginning
}

\author{
J.M. van Poelgeest
}

$1 \quad$ Inleiding

De Crowdfundingverordening is van toepassing met ingang van 10 november $2021 .^{1}$ Deze verordening is een belangrijke stap om crowdfunding in Europa te stimuleren en te uniformeren en het vrije verkeer binnen Europa te bevorderen. $^{2}$

Crowdfunding betreft het ophalen van gelden bij een grotere groep personen of bedrijven via het internet, een online 'platform'. Via het platform kunnen personen of bedrijven aangeven waarvoor, voor welk project, bedragen nodig zijn. Potentiële investeerders op het platform kunnen aan de hand van de via het platform beschikbaar gestelde informatie beoordelen of zij in het betreffende project willen investeren. Bij crowdfunding zijn dus altijd verschillende partijen betrokken. De centrale 'tussen'-partij is het online platform dat partijen bij elkaar brengt. De crowdfunders - ook projecteigenaren genoemd - zijn de partijen die via het platform bedragen wensen te verkrijgen en de investeerders zijn de partijen die mogelijk geïnteresseerd zijn om een bedrag via het platform ter beschikking te stellen aan de projecteigenaren.

In dit artikel wordt ingegaan op de regels die op basis van de Crowdfundingverordening gelden voor crowdfundingplatformen die crowdfundingdiensten (zullen) aanbieden in Europa. Met de inwerkingtreding van deze verordening gaat er een hele set van (andere) regels gelden voor deze crowdfundingdienstverleners, waaronder een vergunningplicht. ${ }^{3}$ Die regels zullen voor een deel van de markt verhelderend en vereenvoudigend zijn omdat de nationale regimes soms ondoorzichtig zijn en daarnaast per lidstaat een ander nationaal regime van toepassing kan zijn. Voor de partijen die nationaal actief zijn op grond van het nationale

1 Verordening (EU) 2020/1503 van het Europees Parlement en de Raad van 7 oktober 2020 betreffende Europese crowdfundingdienstverleners voor bedrijven en tot wijziging van Verordening (EU) 2017/1129 en Richtlijn (EU) 2019/1937.

2 Zie hierover ook J. Baukema, Regulering crowdfunding: nationale ontwikkelingen en ontwerp ECSP Verordening, FR 2018, p. 517-526 en S.N. Demper \& M.L. Louisse, Crowdfunding - een juridische verkenning, Nijmegen: Ars Aequi Libri 2019.

3 Over de crowdfundingregels in Nederland voorafgaand aan inwerkingtreding van de verordening: J.M. van Poelgeest, Crowdfunding en compliance, TvCo 2017, p. 122-126, J.M. van Poelgeest, Crowdfunding, mede mogelijk gemaakt door de wetgever?, O\&F 2014, p. 38-61, J.M. van Poelgeest, Crowdfunding in 2016, Bb 2016/24, p. 99-104 en S.N. Demper \& M.L. Louisse, Regulering van crowdfunding: een update, TOP 2017/145. 
regime, kan de impact echter relatief groot zijn, waarbij de overgang naar het (Europese) crowdfundingregime weinig voordelen hoeft op te leveren.

Bij crowdfunding zijn altijd de eerder genoemde, verschillende partijen betrokken. De Crowdfundingverordening heeft grote gevolgen voor de positie van de crowdfundingplatformen, maar heeft zeker ook impact op de positie van de partijen die effecten uitgeven of funding verkrijgen middels leningen via een platform dat onder de Crowdfundingverordening valt. Indirect zijn er ook gevolgen voor de positie van de (potentiële) investeerders. Door de Crowdfundingverordening gelden er namelijk andere rechten voor en verplichtingen in relatie tot de (potentiële) investeerders ten opzichte van de situatie voor inwerkingtreding van de Crowdfundingverordening.

In dit artikel wordt beoordeeld wat de juridische impact is van de Crowdfundingverordening op de positie van de crowdfundingplatformen (de Crowdfundingverordening noemt deze partijen crowdfundingdienstverleners, zodat in de rest van dit artikel bij deze term zal worden aangesloten) die onder het toepassingsbereik vallen, en wat de gevolgen zullen zijn voor projecteigenaren. In dit verband wordt eerst ingegaan op een belangrijk onderdeel van de Crowdfundingverordening voor de crowdfundingdienstverleners, namelijk de vergunningplicht (par. 2). Vervolgens wordt de reikwijdte van de crowdfundingverordening besproken, zodat kan worden bepaald welke partijen een vergunning nodig hebben en welke projecteigenaren onder het bereik van de verordening (kunnen) vallen (par. 3). In paragraaf 4 wordt ingegaan op de (uitgebreide) eisen voor de crowdfundingdienstverleners die een vergunning wensen of dienen aan te vragen. Hierbij komt ook de vraag aan de orde welke diensten een crowdfundingdienstverlener kan verlenen en wanneer additionele vergunningen nodig kunnen zijn (par. 5). Omdat de Crowdfundingverordening niet alleen een grote impact heeft op de positie van de crowdfundingdienstverlener, maar ook op de positie van de projecteigenaar (de crowdfunder), wordt in paragraaf 6 ingegaan op de positie van de projecteigenaar.

\section{Vergunningplicht crowdfundingdienstverlener}

Met de inwerkingtreding van de Crowdfundingverordening gaat een vergunningplicht gelden voor crowdfundingplatformen/-dienstverleners. ${ }^{4}$ Voor partijen in Nederland geldt dat de crowdfundingvergunning kan worden aangevraagd bij de Autoriteit Financiële Markten (AFM), via het portal van de AFM. ${ }^{5}$ De vergunning

4 Een crowdfundingdienstverlener is gedefinieerd als een rechtspersoon die crowdfundingdiensten verleent. Een crowdfundingvergunning is vereist op grond van art. 12 Crowdfundingverordening.

5 Portal.afm.nl. Hiervoor dient de aanvrager eerst een account aan te maken. De vergunning moet worden aangevraagd bij de toezichthouder in de lidstaat van vestiging. Om een vergunning aan te vragen moet er sprake zijn van een rechtspersoon die in de Europese Unie is gevestigd. 
wordt aangevraagd in de lidstaat van herkomst, zodat alleen partijen die zijn gevestigd in Nederland een vergunning aanvragen bij de AFM. ${ }^{6}$

Een vergunning is nodig voor het verlenen van een 'crowdfundingdienst'. Dit is gedefinieerd in de Crowdfundingverordening als het matchen van bedrijfsfinancieringsbelangstellingen van beleggers en projecteigenaren door het gebruik van een crowdfundingplatform, bestaande uit een van de volgende activiteiten:

1 het faciliteren van het verstrekken van leningen;

2 het plaatsen zonder plaatsingsgarantie als bedoeld in deel A, punt 7, van bijlage I bij Richtlijn 2014/65/EU, van door projecteigenaren of een special purpose vehicle uitgegeven effecten en voor crowdfunding toegelaten instrumenten, en de ontvangst en doorgifte van orders van cliënten als bedoeld in punt 1 van dat deel, met betrekking tot die effecten en voor crowdfunding toegelaten instrumenten. ${ }^{7}$

Samengevat betreft het platformen waar investeerders en projecteigenaren bij elkaar worden gebracht, waarbij sprake is van het aantrekken van zakelijke leningen door de projecteigenaar of het uitgeven van effecten door de projecteigenaar via het platform.

Als een vergunning wordt aangevraagd, wordt daarbij de benodigde informatie verstrekt, zodat de AFM kan beoordelen of aan alle voorwaarden zoals opgenomen in de Crowdfundingverordening wordt voldaan. ${ }^{8}$ Het betreft een breed scala van informatie. Samengevat dient informatie te worden verstrekt over de crowdfundingdienstverlener, de governance en de bestuurders van de crowdfundingdienstverlener en de beoogde activiteiten, over de procedures en systemen en over de financiële situatie. Aan de hand van de vergunningaanvraag wordt binnen 25 dagen beoordeeld of de aanvraag volledig is. Binnen drie maanden na ontvangst van een volledige aanvraag wordt door de bevoegde autoriteit bepaald of de vergunning wordt verleend. ${ }^{9}$

De mogelijkheid om een vergunningaanvraag af te wijzen is redelijk breed geformuleerd. Het betreft objectieve en aantoonbare redenen om aan te nemen dat er een bedreiging zou kunnen zijn voor doeltreffend, gezond en prudent beheer en de bedrijfscontinuïteit, of als er een bedreiging zou kunnen zijn voor een toereikende afweging van belangen van cliënten en de integriteit van de markt. ${ }^{10}$

6 Het is niet mogelijk om een crowdfundingvergunning aan te vragen indien de aanvrager is gevestigd in een derde land.

7 Zie https://eur-lex.europa.eu/legal-content/NL/TXT/?uri=CELEX\%3A02014L0065-20200326. Effecten zijn effecten als bedoeld in art. 4 Richtlijn 2014/65. Voor crowdfunding toegelaten instrumenten zijn met betrekking tot elke lidstaat aandelen van een besloten vennootschap met beperkte aansprakelijkheid die niet onderworpen zijn aan beperkingen die de overdracht ervan effectief zouden verhinderen, waaronder beperkingen van de wijze waarop die aandelen aan het publiek worden aangeboden of bekendgemaakt.

8 Art. 12 Crowdfundingverordening.

9 Art. 12 lid 4 en 8 Crowdfundingverordening.

10 Art. 12 lid 8 en art. 4 Crowdfundingverordening. Door de brede formulering lijkt de tekst interpretatiemogelijkheden te bieden aan de toezichthouders. Dat zou de harmoniserende werking van de Crowdfundingverordening kunnen beperken. 
De verordening - en daarmee de vergunningplicht - voor crowdfundingdienstverleners treedt per 10 november 2021 in werking. Er geldt een overgangsregime voor bestaande crowdfundingplatformen. Dat betekent dat deze partijen de activiteiten nog tot en met 10 november 2022 kunnen voortzetten op basis van het nationale recht. ${ }^{11}$ Hoewel in een eerder voorstel voor de Crowdfundingverordening nog een optie bestond om te kiezen tussen een vergunning op grond van de verordening en een vergunning of andere nationale regeling, is die optie in de finale versie van de Crowdfundingverordening vervallen. Iedere partij die onder de reikwijdte van de Crowdfundingverordening valt, zal dus de vergunning moeten aanvragen op grond van deze verordening. Daarnaast zal er in ieder geval in Nederland ook nog wel een nationaal regime blijven bestaan voor partijen die (geheel of gedeeltelijk) buiten het toepassingsbereik van de verordening vallen. Zoals verderop in dit artikel aan de orde zal komen, zijn dit bijvoorbeeld partijen die diensten verlenen met betrekking tot consumentenkrediet en partijen die (eerst) zelf (zakelijk of consumptief) krediet verstrekken, waarbij daarna pas een investering wordt gedaan door de investeerders.

Een belangrijk voordeel van de vergunning is dat deze ook kan worden gebruikt om crowdfundingdiensten te verlenen in andere Europese staten. Het 'paspoortregime', dat ook geldt voor diverse andere financiële ondernemingen, wordt daarmee als standaard geïntroduceerd voor crowdfundingplatformen. In de lidstaat van herkomst wordt door de crowdfundingdienstverlener aan de eigen toezichthouder in de lidstaat van herkomst aangegeven in welke andere Europese staten de diensten zullen worden verricht. $\mathrm{Na}$ een notificatie in dit verband door de toezichthouder van de lidstaat van herkomst aan de toezichthouder(s) in de andere relevante lidstaten kunnen de diensten in die staten worden verleend op basis van de vergunning verkregen in de lidstaat van herkomst. ${ }^{12}$ Op deze manier hoeft bij het verlenen van de crowdfundingdiensten niet in de verschillende lidstaten te worden nagegaan of een vergunning geldt in die lidstaat en/dan wel er wellicht andere crowdfundingverboden, -ontheffingen of -registraties nodig zijn in verband met het verlenen van de crowdfundingdiensten.

Financiële ondernemingen die al een vergunning hebben op grond van de Wet op het financieel toezicht (Wft), zoals banken, elektronischgeldinstellingen, betaaldienstverleners en beleggingsondernemingen, zijn niet uitgezonderd van de vergunningplicht voor crowdfundingplatformen. Als deze partijen crowdfundingdiensten willen bieden, zullen zij dus een additionele vergunning moeten

11 Art. 48 Crowdfundingverordening. Lidstaten beschikken over de optie om een vereenvoudigde procedure toe te passen voor bestaande crowdfundingdienstverleners.

12 Art. 18 Crowdfundingverordening. Er kan worden gestart met de diensten in de andere staten na vijftien kalenderdagen na het indienen van de informatie bij de toezichthouder van de lidstaat van herkomst of na ontvangst van een mededeling van de toezichthouder van de lidstaat van herkomst dat de andere toezichthouders zijn geïnformeerd (art. 15 lid 2 en 3 Crowdfundingverordening). 
aanvragen. ${ }^{13}$ Wel zal een vereenvoudigde procedure van toepassing dienen te zijn en hoeven documenten die reeds zijn verstrekt aan de toezichthouder niet nogmaals te worden verstrekt. ${ }^{14}$

Alle vergunninghoudende crowdfundingdienstverleners met een vergunning op grond van de Crowdfundingverordening worden opgenomen in een openbaar register van de European Securities and Markets Authority (ESMA). ${ }^{15}$

Als een crowdfundingdienstverlener een vergunning heeft verkregen, kunnen crowdfundingdiensten worden verleend. Wat betekent dit voor het platform? Belangrijk is uiteraard dat als platform kan worden gefungeerd, zodat partijen bij elkaar kunnen worden gebracht. In aanvulling daarop is het toegestaan om een zogeheten 'prikbord' te beheren. Hier kunnen gebruikers van het platform adverteren voor hun koop- en verkoopintenties die eerder op/via het platform zijn aangeboden. Het prikbord mag echter niet functioneren als een intern matchingsysteem of op andere wijze koop en verkoopintenties bij elkaar brengen zodat er een overeenkomst uit voortvloeit. ${ }^{16}$

Het is voor het platform mogelijk om daarnaast nog andere diensten te verlenen. Er geldt geen verbod op het nevenbedrijf, zoals dit wel bestaat voor enkele andere vergunninghoudende financiële ondernemingen. ${ }^{17}$ Een crowdfundingdienstverlener kan in verband met de crowdfundingdiensten bijvoorbeeld betaaldiensten verlenen (voor de afhandeling van de betaalstromen) of consumentenkrediet aanbieden (waarbij investeerders vervolgens in de leningen kunnen investeren), mits de dienstverlener hiertoe de benodigde (andere) vergunningen heeft verkregen. ${ }^{18}$ Als een crowdfundingdienstverlener activiteiten verricht in verband met zakelijke leningen, heeft de dienstverlener - zonder dat hiervoor een additionele vergun-

13 Dit is anders dan bij diverse andere vergunningen, waarbij een uitzondering is gecreëerd voor bepaalde partijen die reeds over een (zwaardere) vergunning beschikken. Het zou voor de hand liggen als personen die reeds in het kader van de Wft zijn gecontroleerd op betrouwbaarheid, ook voor de toets in het kader van deze verordening (art. 12 lid 2 en overweging 23 en 32 Crowdfundingverordening) geacht worden betrouwbaar te zijn (gelijk aan art. 3:9 lid 2, 3:99 lid 2 en 4:10 $\operatorname{lid} 2 \mathrm{Wft}$ ).

14 Overweging 35 Crowdfundingverordening bepaalt het volgende: 'Met het oog op deugdelijk toezicht en het voorkomen van onevenredige administratieve lasten, moeten entiteiten waaraan uit hoofde van Richtlijn 2009/110/EG van het Europees Parlement en de Raad (9) of uit hoofde van Richtlijn 2013/36/EU, 2014/65/EU of (EU) 2015/2366 een vergunning is verleend en die voornemens zijn crowdfundingdiensten aan te bieden, zowel over een vergunning uit hoofde van een van die richtlijnen als over een vergunning uit hoofde van de onderhavige verordening kunnen beschikken. In dergelijke gevallen moet een vereenvoudigde vergunningsprocedure van toepassing zijn en mogen de bevoegde autoriteiten niet verlangen dat documenten of bewijs worden overgelegd waarover zij reeds beschikken.'

15 Art. 12 en 14 Crowdfundingverordening.

16 Voor een interessante analyse van het verschil tussen lening en effect in verband met de Crowdfundingverordening wordt verwezen naar E.L.M. van Kranenburg \& D.A.J.M. Melchers, De toekomstige Europese Verordening voor crowdfundingdienstverleners (deel II), FR 2020, afl. 12, p. 1-7.

17 Art. 12 Crowdfundingverordening.

18 Hiervoor heeft het platform dan een andere vergunning nodig (in Nederland op basis van art. 2:3a respectievelijk art. 2:60 Wft). 
ning nodig is - de mogelijkheid om portefeuillebeheer van leningen aan te bieden. Dit individuele beheer van leningen is gedefinieerd als: 'de toekenning door de crowdfundingdienstverlener van een vooraf bepaald bedrag aan gelden van een belegger, die een oorspronkelijke kredietverstrekker is, aan een of meer crowdfundingprojecten op zijn crowdfundingplatform overeenkomstig een individueel, door de respectieve belegger op discretionaire basis verstrekt mandaat'. ${ }^{19}$ Bij het portefeuillebeheer dient de crowdfundingdienstverlener de opgegeven parameters in acht te nemen en dient de dienstverlener alle nodige maatregelen te nemen om het best mogelijke resultaat voor de beleggers te behalen. ${ }^{20}$

\section{$3 \quad$ Reikwijdte Crowdfundingverordening}

De Crowdfundingverordening ziet uitsluitend op crowdfundingplatformen waarbij partijen bij elkaar worden gebracht. Dat betekent dat structuren waarbij de crowdfundingdienstverlener zelf bijvoorbeeld (eerst) het krediet verstrekt en er vervolgens een cessie plaatsvindt naar investeerders, buiten het bereik van de Crowdfundingverordening vallen. ${ }^{21}$ Uit de Crowdfundingverordening volgt namelijk dat structuren waarbij de crowdfundingdienstverlener als schuldeiser van de projecteigenaar optreedt buiten het bereik van de verordening vallen. Voor deze partijen zal derhalve het nationale regime kunnen blijven bestaan. Voor wat betreft leningen ziet de Crowdfundingverordening uitsluitend op zakelijke leningen. Crowdfunding met betrekking tot consumentenkrediet - dus waarbij de partij die de gelden wenst te ontvangen een consument is - valt ook niet onder de reikwijdte van de verordening. Hierbij kan worden gedacht aan platformen waar consumenten gelden kunnen opvragen voor de aankoop van een woning, een verbouwing of vakantie. Dat betekent dat als de crowdfundingdienstverlener via het platform ook (consumptief of hypothecair) krediet aan consumenten wil verstrekken of wil kunnen laten verstrekken, een additionele vergunning nodig is op grond van de nationale regelgeving. ${ }^{22}$ In Nederland is dat een AFM-vergunning voor het aanbieden van krediet. Dergelijke vergunninghouders zullen bijvoorbeeld overkreditering van de consumenten moeten voorkomen en dus uitgebreid moeten toetsen of een consument de beoogde lening kan dragen.

Een consument is een natuurlijke persoon die niet handelt in de uitoefening van beroep of bedrijf. Of een persoon wordt aangemerkt als een consument, kan worden uitgelegd aan de hand van Europese interpretaties en jurisprudentie. Het

19 Art. 2 lid 1 sub c Crowdfundingverordening.

20 Art. 3 lid 4 Crowdfundingverordening. Voor het vormgeven van individueel portefeuillebeheer van leningen wordt ook verwezen naar art. 6 Crowdfundingverordening.

21 Overweging 11 Crowdfundingverordening en de definitie van crowdfundingdienst zoals opgenomen in art. 2 Crowdfundingverordening.

22 In Nederland is dat een vergunning op grond van art. 2:60 Wft. Overweging 8 Crowdfundingverordening. 
begrip consument is opgenomen in diverse Europese regelgeving, waaronder de richtlijn consumentenkrediet en de richtlijn hypothecair krediet. ${ }^{23}$

De Crowdfundingverordening ziet op crowdfunding waarbij leningen worden aangetrokken of effecten zoals aandelen of obligaties worden uitgegeven. Dat betekent dat als de projecteigenaar een ander type product, zoals cryptocurrency, wenst uit te geven via het platform waarbij die cryptocurrency niet kwalificeert als een effect, ${ }^{24}$ dit niet valt onder de Crowdfundingverordening. ${ }^{25}$ Ook als er schenkingen/donaties plaatsvinden middels crowdfunding valt de activiteit niet onder de Crowdfundingverordening.

De Crowdfundingverordening ziet daarnaast alleen op projecteigenaars die een beperkt bedrag aan funding nodig hebben. Per projecteigenaar kan via het crowdfundingplatform, gerekend over een periode van twaalf maanden, $€ 5$ miljoen worden opgehaald. Dit omvat dan alle aanbiedingen via het/een crowdfundingplatform en ziet dus zowel op leningen als op effecten. ${ }^{26}$

\section{Eisen voor crowdfundingdienstverleners}

Voor crowdfundingdienstverleners die een vergunning willen aanvragen en behouden, gelden diverse eisen op grond van de Crowdfundingverordening. ${ }^{27}$ Een aantal punten in de Crowdfundingverordening zal door ESMA nog verder worden uitgewerkt, in zogeheten Regulatory Technical Standards (RTS). ${ }^{28}$ De eisen waar de crowdfundingdienstverleners aan moeten voldoen, worden in het hiernavolgende kort besproken.

23 Richtlijn 2008/48 en Richtlijn 2014/17. In principe zou vervolgens (online) het krediet ook in andere lidstaten moeten kunnen worden aangeboden op basis van de e-commercerichtlijn (Richtlijn 2000/31), waarbij per lidstaat zal moeten worden geverifieerd of dit inderdaad mogelijk is op basis van de nationale wet- en regelgeving (waarin de richtlijn zou moeten zijn geïmplementeerd).

24 Effecten of voor crowdfunding toegelaten instrumenten.

25 Voor de toekomst is beoogd dat bepaalde activiteiten in verband met het uitgeven van cryptocurrency/tokens onder de 'MiCA-verordening' vallen. Overweging 15 Crowdfundingverordening en het voorstel voor een verordening van het Europees Parlement en de Raad betreffende markten in cryptoactiva en tot wijziging van Richtlijn 2019/1937 (COM(2020)593 final, MICA).

26 Overweging 16 en art. 1 lid 2 sub c Crowdfundingverordening. Op basis van de beschikbare informatie heb ik nog niet sluitend kunnen vaststellen op welke wijze de berekening van de twaalf maanden zal dienen plaats te vinden. De AFM hanteert voor de $€ 5$ miljoenvrijstelling in verband met de prospectusplicht een berekening waarbij alle aanbiedingen in de voorafgaande twaalf maanden worden meegeteld. Een eerdere aanbieding telt in deze interpretatie mee als het einde van de aanbiedingsperiode binnen de bedoelde twaalf maanden valt (AFM Q\&A: vrijstelling prospectusplicht, februari 2020). De Europese interpretatie in verband met de berekening zal doorslaggevend zijn.

27 Art. 12 Crowdfundingverordening. Zie voor een beschrijving van de verplichtingen die gelden voor crowdfundingdienstverleners ook Van Kranenburg \& Melchers 2020.

28 Dit omvat regels rondom het klachtenreglement, het bedrijfscontinuïteitsplan, de belangenverstrengelingregeling, de vergunningaanvraag en de toelatingskennistest voor niet-ervaren beleggers. ESMA zal deze RTS in 2021 ter consultatie voorleggen aan het publiek. Er is een consultatiedocument gepubliceerd (26 februari 2021: ESMA35-36-2201): https://www.esma.europa.eu/ press-news/esma-news/esma-consults-regulating-crowdfunding 


\subsection{Beleggersbescherming}

Beleggersbescherming is een van de doelstellingen van de verordening en dit komt ook terug in de verplichtingen die gelden voor de crowdfundingdienstverleners. Voor crowdfundingdienstverleners is bepaald dat zij eerlijk, rechtvaardig, professioneel en in overeenstemming met de belangen van hun cliënten (de (potentiële) investeerders en de (potentiële) projecteigenaren) handelen. ${ }^{29}$ De eisen die gelden voor de crowdfundingdienstverlener zijn in verband met de door de verordening beoogde beleggersbescherming deels afgestemd op het type investeerder. Indien de investeerders minder professioneel worden geacht, wordt van de crowdfundingdienstverlener meer verwacht ten opzichte van de investeerder dan wanneer er sprake is van een meer professionele investeerder. Dit resulteert in de Crowdfundingverordening in een onderscheid tussen de 'ervaren belegger' en de 'niet-ervaren belegger'. ${ }^{30}$ Om ervoor te zorgen dat ook niet-ervaren beleggers inzicht hebben in het risiconiveau in verband met de crowdfundingprojecten moet de crowdfundingdienstverlener een toelatingstest doen. ${ }^{31} \mathrm{Op}$ basis van deze test wordt beoordeeld of, en zo ja, welke crowdfundingdiensten geschikt zijn voor de betreffende niet-ervaren belegger. De niet-ervaren belegger zal in dit verband diverse informatie moeten verstrekken aan de crowdfundingdienstverlener, waaronder over zijn of haar ervaring, beleggingsdoelstellingen en financiële situatie. Als uit de test blijkt dat er onvoldoende kennis, vaardigheden en ervaring is, moet de investeerder worden gewaarschuwd dat de diensten ongeschikt zouden kunnen zijn. Deze investeerders zullen ook moeten bevestigen dat ze de risico's onderkennen. Specifiek voor de niet-ervaren beleggers is nog een additionele beschermingsregel ingevoerd. Voor deze personen geldt een bedenktijd van vier kalenderdagen. ${ }^{32}$

Voor wat betreft de vergoedingen is bepaald dat de crowdfundingdienstverleners geen vergoeding, korting of niet-geldelijk voordeel betalen of aanvaarden voor het geleiden van orders van beleggers naar een bepaald crowdfundingaanbod op hun crowdfundingplatform of naar een bepaald crowdfundingaanbod op een crowdfundingplatform van een derde. ${ }^{33}$ Beoogd is dat aan potentiële investeerders op neutrale basis beleggingsmogelijkheden worden aangeboden, zodat het voor crowdfundingdienstverleners niet is toegestaan om een vergoeding, korting of niet-gelijk voordeel te betalen of te aanvaarden voor het geleiden van orders van beleggers in de richting van een bepaald aanbod op hun platform of het platform van een derde. ${ }^{34}$

29 Art. 3 lid 2 Crowdfundingverordening.

30 Art. 2 Crowdfundingverordening. Verwezen wordt ook naar overweging 42 Crowdfundingverordening. Wat ervaren beleggers zijn, is uiteengezet in bijlage 2 bij de Crowdfundingverordening.

31 Art. 21 Crowdfundingverordening.

32 Art. 22 Crowdfundingverordening. Zie hierover ook Van Kranenburg \& Melchers 2020.

33 Art. 3 lid 3 Crowdfundingverordening.

34 Overweging 19 Crowdfundingverordening. 


\subsection{Selectie projecten en zorgvuldigheid}

Crowdfundingdienstverleners zullen een beleid moeten voeren om ervoor te zorgen dat projecten op professionele, eerlijke en transparante wijze worden geselecteerd. De crowdfundingdienstverlener zal, voordat een project op het platform wordt geplaatst, een onderzoek moeten doen naar de projecteigenaar.

In dit verband dient in ieder geval te worden nagegaan of de projecteigenaar geen strafblad heeft met betrekking tot inbreuken op nationale regels op het gebied van handelsrecht, insolventierecht, financiële diensten, bestrijding van het witwassen van geld, fraudebestrijding of beroepsaansprakelijkheidsverplichtingen, en er moet worden vastgesteld dat de projecteigenaar niet is gevestigd in een niet-coöperatief land of in een derde land met een hoog risico. ${ }^{35}$ In Nederland kan in dit verband bijvoorbeeld worden gewerkt met een antecedentenverklaring van de projecteigenaar. Daarnaast kunnen openbare bronnen worden geraadpleegd, waaronder de insolventieregisters, ${ }^{36}$ en kan worden bekeken of er maatregelen van (financiële) toezichthouders zijn gepubliceerd. ${ }^{37}$

Mede in verband met de informatieverplichtingen die gelden voor de crowdfundingdienstverlener ten opzichte van de (potentiële) investeerders zal niet alleen een uitgebreid onderzoek worden gedaan naar de projecteigenaar, maar ook naar het (beoogde) project. ${ }^{38}$

De Wet ter voorkoming van witwassen en financieren van terrorisme (Wwft) lijkt voor crowdfundingdienstverleners die geen additionele diensten verlenen niet direct van toepassing te zijn op basis van de tekst van de Crowdfundingverordening. ${ }^{39}$ Uit de EBA guidelines inzake de anti-witwasregelgeving volgt echter wel dat er ook van crowdfunding platforms bepaalde eisen gelden op dit gebied. ${ }^{40}$ Praktisch gezien zal in ieder geval wel een soortgelijk onderzoek naar

35 Art. 5 Crowdfundingverordening.

36 Zie https://insolventies.rechtspraak.nl/\#!/zoeken/index.

37 Het uitgangspunt op basis van de Wft is dat als een boete wordt opgelegd, deze boete ook wordt gepubliceerd.

38 Bovendien kunnen op die wijze ook oneerlijke handelspraktijken worden voorkomen. Crowdfundingdienstverleners kunnen wel onder de Wwft vallen. Als de crowdfundingdienstverlener bijv. ook de betaaldiensten zelf verricht, valt de dienstverlener uit dien hoofde echter toch onder de Wwft. Daarnaast kan worden gedacht aan platformen die ook andere beleggingsdiensten verlenen en in dat verband ook beschikken over een vergunning als beleggingsonderneming. Ook zal aan de sanctieregels moeten worden voldaan.

39 Als de crowdfundingdienstverlener bijv. ook de betaaldiensten zelf verricht of ook additionele diensten verleent zoals het aanbieden van consumentenkrediet of het verlenen van (andere) beleggingsdiensten, valt de dienstverlener uit dien hoofde echter toch/alsnog onder de Wwft. Mijns inziens geldt de Wwft dan in beginsel voor alle professionele diensten van de crowdfundingdienstverlener en ziet de Wwft dan niet alleen op de betaaldiensten die worden verleend.

40 EBA final report, 1 March 2021, Guidelines on customer due diligence and the factors credit and financial institutions should consider when assessing the money laundering and terrorist financing risk associated with individual business relationships and occasional transactions ('The ML/ TF Risk Factors Guidelines') under Articles 17 and 18(4) of Directive (EU) 2015/849. 
projecteigenaren en andere derde partijen moeten plaatsvinden. ${ }^{41}$ Ook zal aan de sanctieregels moeten worden voldaan.

\subsection{Doeltreffende en prudente bedrijfsvoering}

In verband met de doeltreffende en prudente bedrijfsvoering dienen beleidsregels en procedures te worden vastgesteld. ${ }^{42}$ Deze beleidsregels en procedures omvatten de scheiding van verantwoordelijkheden, bedrijfscontinuiteit ${ }^{43}$ en het voorkomen van belangenconflicten. Dit gebeurt zodanig dat de integriteit van de markt en de belangen van cliënten worden bevorderd. Voor activiteiten in verband met leningen geldt dat geschikte systemen en controles moeten worden ingesteld om de risico's in verband met de leningen te beoordelen. ${ }^{44}$

Als de crowdfundingdienstverlener de - correcte en passende - prijs van het crowdfundingaanbod bepaalt, gelden daarvoor ook diverse vereisten. De dienstverlener zal een redelijke beoordeling van het kredietrisico moeten uitvoeren. Hierbij moet in geval van een lening, obligatie of andere gesecuritiseerde schuld onder meer het risico worden meegenomen dat de projecteigenaar een of meerdere terugbetalingen niet zal verrichten. ${ }^{45}$ Ook moet voldoende informatie worden meegenomen in deze kredietbeoordeling.

Leningen moeten worden gewaardeerd op het moment dat de lening wordt geïnitieerd, maar ook als de projecteigenaar waarschijnlijk de verplichtingen niet zal nakomen, in geval van verzuim en indien het voor de kredietverstrekker mogelijk wordt gemaakt voor de vervaldatum uit te stappen. De crowdfundingdienstverlener zal ook een register bijhouden om aan te kunnen tonen dat en op welke wijze de kredietbeoordeling is uitgevoerd en dat de prijs correct en passend was. ${ }^{46}$

\subsection{Klachtenbehandeling, belangenconflicten en uitbesteding}

Voor de crowdfundingdienstverlener geldt dat hij ook bepaalde procedures moet opstellen in verband met klachtenbehandeling, belangenconflicten en uitbesteding. Crowdfundingdienstverleners dienen te beschikken over doeltreffende en transparante procedures voor een snelle, correcte en consistente behandeling van klachten van cliënten en dienen de procedure ook bekend te maken. Er moet ook een standaardmodel zijn voor klachten dat aan cliënten ter beschikking wordt gesteld. Tevens hanteert de dienstverlener een klachtenregister. ${ }^{47}$

41 Niet alleen om aan de eigen verplichtingen te voldoen, maar bijv. ook in verband met de samenwerkingsverbanden met andere ondernemingen waar de Wwft wel voor geldt, zoals banken en betaaldienstverleners.

42 Art. 4 Crowdfundingverordening.

43 Een bedrijfscontinuïteitsplan is vereist om de risico's in verband met het uitvallen van een crowdfundingdienstverlener te ondervangen. Art. 12 lid 2 sub j, art. 4 lid 3 en overweging 25 Crowdfundingverordening.

44 Art. 4 lid 2 Crowdfundingverordening.

45 Art. 4 lid 4 Crowdfundingverordening.

46 Art. 4 lid 4 Crowdfundingverordening. Het uitvoeren van de waardering van de lening op het moment dat de kredietverstrekker kan uitstappen, lijkt te zien op een eenmalig moment en niet op de situatie dat er vervroegde aflossing mogelijk is op ieder moment. In dat geval zou in mijn interpretatie dan uitsluitend het moment van de beoogde (vervroegde) aflossing relevant zijn.

47 Art. 7 Crowdfundingverordening. Zie ook overweging 23 Crowdfundingverordening. 
Gelet op de online diensten van het crowdfundingplatform, lijkt het daarnaast nodig om te verwijzen naar het Europese online geschillenplatform. ${ }^{48}$ Dit is een online platform waar consumenten een klacht online kunnen deponeren, zodat kan worden bepaald waar en bij welk instituut de klacht uiteindelijk kan worden ingediend en behandeld.

Klachten worden tijdig en correct onderzocht en de uitkomst wordt binnen een redelijke termijn meegedeeld aan de klager. ESMA zal nog technische reguleringsnormen vaststellen in verband met klachtenbehandeling. ${ }^{49}$

De crowdfundingdienstverlener zal ervoor moeten zorgen dat belangenconflicten worden voorkomen en zal hiertoe interne regels moeten hanteren. ${ }^{50}$ Een belangrijke voorwaarde is dat crowdfundingdienstverleners zelf geen deelneming hebben in een crowdfundingaanbod op hun crowdfundingplatform en dat aandeelhouders die $20 \%$ of meer van het aandelenkapitaal of de stemrechten bezitten van de crowdfundingdienstverlener niet mogen optreden als projecteigenaren. Ook bestuurders en werknemers mogen niet optreden als projecteigenaar. Hetzelfde geldt voor aan deze aandeelhouders, bestuurders en werknemers verbonden personen door middel van een zeggenschapsband. ${ }^{51}$ Dit is mede relevant omdat deze situatie zich in de praktijk nog wel eens voordoet om de start van de crowdfundingactiviteiten te bevorderen.

Indien de betreffende personen als belegger worden aanvaard, maakt de crowdfundingdienstverlener dit volledig openbaar op de website, inclusief informatie over de specifieke projecten. De aard en de bronnen van belangenconflicten en van de genomen maatregelen ter beperking van die belangenconflicten worden eveneens openbaar gemaakt op de website. ${ }^{52}$

Er gelden ook regels omtrent uitbesteding. De crowdfundingdienstverlener moet redelijke maatregelen nemen om een extra operationeel risico te vermijden. De uitbesteding mag de kwaliteit van de interne controle en de mogelijkheden om toezicht te houden niet beperken. ${ }^{53}$ Deze uitbestedingsregels zijn soortgelijk aan de uitbestedingsregels die gelden voor andere financiële ondernemingen die een vergunning op grond van de Wft hebben. Dit betekent dat er een uitbestedingsbe-

48 Zie https://ec.europa.eu/consumers/odr/main/?event=main.home2.show. Dit volgt uit de richtlijn alternatieve beslechting van consumentengeschillen (Richtlijn 2013/11, richtlijn ADR consumenten).

49 Art. 7 lid 5 Crowdfundingverordening. Uit de verordening volgt niet direct dat/of de crowdfundingdienstverleners zich aan zullen moeten sluiten bij het Klachteninstituut financiële dienstverleners (het Kifid).

50 Overweging 26, art. 4 en 8 Crowdfundingverordening.

51 Het betreft een zeggenschapsband als gedefinieerd in art. 4 lid 1 punt 35 sub b Richtlijn 2014/65/EU: 'de band die bestaat tussen een moederonderneming en een dochteronderneming, in alle gevallen zoals bedoeld in artikel 22, leden 1 en 2, van Richtlijn 2013/34/EU, of een band van dezelfde aard tussen een natuurlijke of rechtspersoon en een onderneming; elke dochteronderneming van een dochteronderneming wordt ook beschouwd als een dochteronderneming van de moederonderneming die aan het hoofd van deze ondernemingen staat'.

52 Art. 8 Crowdfundingverordening. ESMA stelt technische reguleringsnormen op in verband met het voorkomen van belangenconflicten.

53 Art. 9 Crowdfundingverordening. 
leid zal moeten worden opgesteld en dat de uitbestedingsovereenkomst aan bepaalde voorwaarden moet voldoen. Zo zal er bijvoorbeeld voor moeten worden gezorgd dat de derde op verzoek direct alle informatie in verband met de uitbestedingsdiensten ter beschikking stelt aan de crowdfundingdienstverlener en op verzoek informatie beschikbaar stelt voor de betreffende toezichthouders. Bij uitbesteding door de crowdfundingdienstverlener kan bijvoorbeeld worden gedacht aan het uitbesteden van de sanctiechecks op basis van de sanctieregelingen. Op basis van de sanctieregelingen moet bijvoorbeeld worden gecontroleerd of een (potentiële) client is opgenomen op een van de sanctielijsten, omdat dan geen diensten (meer) aan die persoon mogen worden verleend. Ook kan worden gedacht aan een partij die wordt ingeschakeld voor het opslaan van data in de cloud.

\subsection{Prudentiële eisen}

Er gelden prudentiële voorwaarden voor de crowdfundingdienstverlener, tenzij de crowdfundingdienstverlener een beleggingsonderneming, bank, elektronischgeldinstelling of betaaldienstverlener is en uit dien hoofde al aan prudentiële eisen moet voldoen. ${ }^{54}$

Crowdfundingdienstverleners beschikken te allen tijde over prudentiële waarborgen die gelijk zijn aan ten minste het hogere bedrag van de volgende twee bedragen:

a $€ 25.000$; en

b een kwart van de vaste kosten van het voorafgaande jaar, die jaarlijks worden geëvalueerd, waaronder de kosten voor het beheren van de leningen voor drie maanden wanneer de crowdfundingdienstverlener ook het verstrekken van leningen faciliteert. ${ }^{55}$

Aan deze prudentiële eis kan op verschillende manieren worden voldaan. Het is mogelijk om hieraan te voldoen door middel van het aanhouden van eigen vermogen, of door een verzekeringspolis of een soortgelijke waarborg dan wel door een combinatie van eigen vermogen en een verzekeringspolis of een soortgelijke waarborg. 56

54 Art. 11 lid 3 en 4 Crowdfundingverordening.

55 Art. 11 Crowdfundingverordening. Zie ook overweging 24 Crowdfundingverordening. Als de dienstverlener nog geen twaalf maanden actief is, kan ook gebruik worden gemaakt van toekomstgerichte bedrijfsramingen. Zodra de gegevens beschikbaar komen, moeten die gegevens alsnog worden gebruikt.

56 Art. 11 Crowdfundingverordening. Het betreft het eigen vermogen bestaand uit tier 1-kernkapitaalbestanddelen. In lid 8 is bepaald hoe de vaste kosten moeten worden berekend. De verzekeringspolis biedt dekking in alle gebieden van de Europese Unie waar crowdfundingaanbiedingen actief op de markt worden gebracht. De polis heeft een looptijd van ten minste een jaar en een opzegtermijn van ten minste negentig dagen, en is gesloten bij een (derde) verzekeraar die bevoegd is op grond van het Unierecht of het nationale recht om verzekeringen te verstrekken. De verordening bepaalt in lid 7 ook in welke dekking de polis moet voorzien. 


\subsection{Informatieverstrekking door de crowdfundingdienstverlener}

Informatieverstrekking door de crowdfundingdienstverlener is een belangrijk onderdeel van de (doorlopende) verplichtingen die gelden voor crowdfundingdienstverleners. De Crowdfundingverordening beoogt (potentiële) investeerders te beschermen en correcte en volledige informatieverstrekking is daar een relevant onderdeel van. De gedachte is dat zolang (potentiële) investeerders maar correct en volledig worden geïnformeerd, zij een bewuste beslissing kunnen maken over de eventuele investering.

Het platform is verplicht om alle potentiële investeerders het (standaard) essentiele informatieblad te verstrekken. ${ }^{57}$ Het essentiële informatieblad moet worden verstrekt door de crowdfundingdienstverlener op een duurzame drager. ${ }^{58}$ Hoewel de verplichting tot het verstrekken van het blad bij de crowdfundingdienstverlener rust, wordt het informatieblad opgesteld door de projecteigenaar. Die is immers het beste in staat de informatie te verzamelen. Het blad wordt opgesteld in de officiële taal van de staat waar de (crowdfunding)vergunning is verkregen of in een (andere) taal die door die lidstaat wordt aanvaard. ${ }^{59}$ Welke taal/talen worden geaccepteerd in een lidstaat zal zichtbaar zijn op de website van ESMA.

De informatie in het informatieblad is correct, duidelijk en niet misleidend. De informatie die in het essentiële informatieblad moet worden verwerkt, is opgenomen in bijlage 1 bij de Crowdfundingverordening. Daarbij wordt de volgende disclaimer opgenomen:

'Dit crowdfundingaanbod is niet geverifieerd noch goedgekeurd door de bevoegde autoriteit of de Europese Autoriteit voor effecten en Markten (ESMA). De geschiktheid van uw ervaring en kennis is niet noodzakelijk beoordeeld voordat $\mathrm{u}$ toegang hebt gekregen tot deze belegging. Door deze belegging te doen, neemt $\mathrm{u}$ het volledige risico op $\mathrm{u}$ van deze belegging, waaronder het risico van gedeeltelijk of volledig verlies van het belegde geld.'

Tevens geldt dat de volgende risicowaarschuwing moet worden opgenomen:

'Beleggen in dit crowdfundingproject brengt risico's met zich mee, waaronder het risico van geheel of gedeeltelijk verlies van het belegde geld. Uw belegging valt niet onder de depositogarantieregelingen die zijn ingesteld overeenkomstig richtlijn 2014/49/EU van het Europees Parlement en de Raad. Evenmin valt uw belegging onder de beleggerscompensatiestelsels die zijn ingesteld overeenkomstig richtlijn 97/9/EG van het Europees Parlement en de Raad. $\mathrm{U}$ ontvangt mogelijk geen rendement op uw belegging. Dit is geen spaarproduct en wij raden $u$ aan niet meer dan $10 \%$ van uw nettovermogen in crowdfundingprojecten te beleggen. $U$ kunt de beleggingsinstrumenten mogelijk 
niet verkopen wanneer $\mathrm{u}$ dat wenst. Zelfs als $\mathrm{u}$ ze wel kunt verkopen, zult $\mathrm{u}$ mogelijk verlies lijden.' 60

Uiteraard gelden ook doorlopende verplichtingen voor crowdfundingdienstverleners. Het essentiële informatieblad dient actueel te blijven. In dit verband is de projecteigenaar verplicht om de crowdfundingdienstverlener te informeren over iedere wijziging in de informatie opgenomen in het informatieblad, zodat het informatieblad door de crowdfundingdienstverlener actueel kan worden gehouden gedurende de periode van het aanbod. ${ }^{61}$ Een andere doorlopende verplichting is dat indien ook diensten worden aangeboden met betrekking tot leningen, alle relevante informatie beschikbaar moet worden gesteld, waaronder de verzuimgraden van de leningen. ${ }^{62}$

\section{- $\quad$ Prospectusverplichting}

Op grond van art. 3 Prospectusverordening ${ }^{63}$ is in beginsel een (goedgekeurd) prospectus vereist indien effecten in de Europese Unie worden aangeboden aan het publiek. Crowdfundingaanbiedingen die worden gedaan op grond van de Crowdfundingverordening (en die derhalve vallen binnen het toepassingsbereik van de Crowdfundingverordening) vallen niet onder de prospectusverplichting zoals opgenomen in art. 3 Prospectusverordening. ${ }^{64}$ Hiervoor geldt een maximum van $€ 5$ miljoen, berekend over een periode van twaalf maanden. ${ }^{65}$ De gedachte hierbij is dat de (potentiële) investeerders voldoende informatie ontvangen in verband met de (beoogde) investeringen op basis van de verplichtingen die al volgen uit de Crowdfundingverordening, zoals het essentiële informatieblad. Bovendien sluit het gehanteerde bedrag goed aan bij de in veel lidstaten gehanteerde uitzondering op de prospectusplicht. ${ }^{66}$ Voor de crowdfundingdienstverlener (en de projecteigenaar) geldt derhalve geen prospectusplicht indien aan de voorwaarden van de Crowdfundingverordening wordt voldaan.

60 Art. 23 lid 6 Crowdfundingverordening.

61 Als het essentiële informatieblad is verstrekt aan de (potentiële) investeerder, dan is daarmee ook voldaan aan een eventuele verplichting om een informatiedocument op grond van de PRIIPsverordening te verstrekken (Verordening 1286/2014).

62 Art. 20 en overweging 40 Crowdfundingverordening.

63 Verordening 2017/1129.

64 Art. 1 lid 2 sub c Crowdfundingverordening en Verordening (EU) 2017/1129. In dit verband is de Prospectusverordening gewijzigd en is aan art. 1 lid 4 Prospectusverordening toegevoegd 'een aanbieding van effecten aan het publiek door een crowdfundingdienstverlener waaraan uit hoofde van Verordening (EU) 2020/1503 van het Europees Parlement en de Raad een vergunning is verleend, mits die aanbieding de in art. 1 lid 2 onder c) van die verordening bepaalde drempel niet overschrijdt'.

65 Art. 1 lid 2 sub c Crowdfundingverordening.

66 Overweging 16 en 67 Crowdfundingverordening. 


\section{Andere vergunningen voor de crowdfundingdienstverlener}

\subsection{Betaaldiensten}

Indien er sprake is van crowdfunding, gaan er betaalstromen van de investeerders naar de projecteigenaar en van de projecteigenaar naar de investeerders. Deze betaalstroom wordt door de crowdfundingdienstverlener gefaciliteerd. Het verwerken van deze betaalstroom levert in beginsel een betaaldienst op.

Voor de betaaldiensten die samenhangen met de crowdfundingdiensten zal de crowdfundingdienstverlener een vergunninghoudende betaaldienstverlener moeten inschakelen of tevens een vergunning moeten hebben of verkrijgen voor het verlenen van betaaldiensten. ${ }^{67}$ Dat is in Nederland een wijziging, omdat De Nederlandsche Bank (DNB) een interpretatie op de website van DNB heeft geplaatst waarin staat dat van 'het bedrijf maken van het verlenen van betaaldiensten' uitsluitend sprake is wanneer sprake is van voor rekening van een betaler of begunstigde verleende betaaldiensten als een zelfstandig identificeerbare activiteit. Dat wil zeggen: een opzichzelfstaande, niet onlosmakelijk verbonden met een andere, niet met het verrichten van betaaldiensten verband houdende activiteit. Een voorbeeld dat hierbij wordt genoemd, zijn crowdfundingplatformen voor zover zij tijdelijk het beheer hebben van geldmiddelen van degenen aan wie door tussenkomst van de platformen leningen worden verstrekt of van degenen die via de platformen geldmiddelen aanbieden of hebben verstrekt, en dat beheer niet opzichzelfstaande activiteiten betreft.

Met de inwerkingtreding van deze Crowdfundingverordening geldt deze interpretatie niet (meer) voor crowdfundingplatformen. Op basis van de verordening geldt dat als een partij een vergunning wenst aan te vragen voor zowel het verlenen van crowdfundingdiensten als het verlenen van de (bijbehorende) betaaldiensten, de betreffende aanvrager de documentatie slechts eenmaal hoeft in te dienen. ${ }^{68}$ In de praktijk in Nederland is dat wellicht omslachtig omdat het twee verschillende toezichthouders zijn, de AFM en DNB. Wel is mogelijk dat de AFM dan bijvoorbeeld de benodigde documentatie ter beschikking stelt aan DNB, maar het lijkt feitelijk eenvoudiger als de instelling de documentatie zelf in zowel het AFM- als het DNB-portaal plaatst met de vermelding dat ook een aanvraag is ingediend bij de andere toezichthouder.

\subsection{Cryptocurrency}

De Europese Commissie heeft een voorstel gepubliceerd om de cryptomarkten op Europees niveau nader te reguleren, namelijk de (concept)verordening Markten in Cryptoactiva (MiCA). Op basis van dit voorstel blijkt dat is beoogd dat als er cryptoassets worden aangeboden, er regels gaan gelden voor de uitgevende instelling. Het publiceren van een white paper zal bijvoorbeeld verplicht worden. Daarnaast is van belang dat is beoogd dat als er bepaalde diensten met betrekking tot cryptoassets worden verleend, zoals diensten waarbij cryptoassets in de markt geplaatst worden en diensten waarbij orders in cryptoassets worden afgewikkeld

67 Art. 10 Crowdfundingverordening. Zie hierover ook overweging 29 Crowdfundingverordening.

68 Art. 12 lid 15 Crowdfundingverordening. 
door derde partijen, bepaalde eisen gaan gelden, zoals dat in beginsel een vergunning verplicht zal zijn. ${ }^{69}$ Dit is van belang voor de crowdfundingdienstverleners die ook crowdfundingdiensten willen verlenen in verband met cryptoassets. Dan zal immers, op basis van het huidige voorstel, naast de vergunning op basis van de Crowdfundingverordening ook nog een vergunning nodig zijn op basis van de $\mathrm{MiCA}$. Voor de MiCA zal de dienstverlener aan andere eisen moeten voldoen.

\subsection{Bewaring effecten}

Effecten of voor crowdfunding toegelaten instrumenten die worden aangeboden op een crowdfundingplatform en die kunnen worden geregistreerd op een op naam van een belegger geopende effectenrekening of die fysiek kunnen worden geleverd aan een bewaarnemer, zullen in bewaring worden genomen door de crowdfundingdienstverlener of door een derde. De partij die de bewaarnemingsdiensten verleent, moet daarvoor over een (aanvullende) vergunning beschikken als bank of beleggingsonderneming. ${ }^{70}$

\subsection{Beleggingsdiensten}

Voor de crowdfundingdiensten die worden verleend op grond van de crowdfundingvergunning en mede kwalificeren als een beleggingsdienst, is geen additionele (MiFID-)vergunning vereist. ${ }^{71}$ Als de crowdfundingdienstverlener, in aanvulling op de beleggingsdiensten die op grond van de crowdfundingvergunning (mogen) worden verleend, nog andere beleggingsdiensten of beleggingsactiviteiten wenst te verlenen, zal hiervoor wel een additionele vergunning bij de AFM moeten worden aangevraagd. ${ }^{72}$ Uit de definitie van crowdfundingdienst blijkt welke beleggingsdiensten zijn toegestaan, namelijk het plaatsen zonder plaatsingsgarantie en het ontvangen en doorgeven van orders. Als de crowdfundingdienstverlener bijvoorbeeld ook vermogensbeheerdiensten wenst aan te bieden, zal een additionele vergunning moeten worden aangevraagd.

69 Voorstel voor een verordening van het Europees Parlement en de Raad betreffende markten in cryptoactiva en tot wijziging van Richtlijn 2019/1937(COM(2020)593 final, MICA).

70 Art. 10 Crowdfundingverordening. Overeenkomstig Richtlijn 2013/36/EU of Richtlijn 2014/65/ EU. Voor een nadere uiteenzetting wordt verwezen naar Van Kranenburg \& Melchers 2020.

71 Art. 1 Richtlijn (EU) 2020/1504 van het Europees Parlement en de Raad van 7 oktober 2020 tot wijziging van Richtlijn 2014/65/EU betreffende markten voor financiële instrumenten (de Crowdfundingrichtlijn), waarmee aan art. 2 lid 1 Richtlijn 2014/65 wordt toegevoegd: 'p) crowdfundingdienstverleners zoals gedefinieerd in artikel 2, lid 1, onder e), van Verordening (EU) 2020/1503 van het Europees Parlement en de Raad'. In overweging 10 van de verordening is opgenomen: 'Deze verordening moet van toepassing zijn op crowdfundingdiensten die bestaan uit de gezamenlijke verlening van de inontvangstneming en doorgifte van cliëntenorders en het plaatsen van effecten of andere voor crowdfunding toegelaten instrumenten zonder plaatsingsgarantie op een openbaar platform dat beleggers onbeperkte toegang biedt.'

72 Art. 2:96 Wft. 
Crowdfunding kan onder meer plaatsvinden door bedrijven en door natuurlijke personen, door donaties, leningen, financiële instrumenten en tokens en voor kleine of hoge bedragen. Gelet op het beschreven toepassingsbereik van de Crowdfundingverordening, zal de projecteigenaar die middels een crowdfundingplatform dat onder de Crowdfundingverordening valt, veelal een rechtspersoon zijn die leningen aantrekt of effecten uitgeeft voor een bedrag van niet meer dan $€ 5$ miljoen. ${ }^{73}$

De Crowdfundingverordening zorgt ervoor dat de regels die gelden voor projecteigenaren die funding aantrekken via een crowdfundingplatform dat onder de verordening valt, grotendeels worden geharmoniseerd.

In het hiernavolgende worden de belangrijkste gevolgen van de Crowdfundingverordening beschreven voor de projecteigenaren.

\subsection{Geen vergunningplicht en geen verbod opvorderbare gelden voor de projecteigenaar}

Een projecteigenaar die funding in de vorm van opvorderbaar geld aantrekt middels een crowdfundingplatform heeft in beginsel geen vergunning naar nationaal recht nodig. ${ }^{74}$ De verordening bepaalt namelijk dat er voor de projecteigenaar geen vergunning als kredietinstelling nodig is of enige andere vergunning, vrijstelling of ontheffing. Hierbij wordt verwezen naar 'projecteigenaren die door de crowdfundingdienstverlener gefaciliteerde leningen aanvaarden'. Het is mijns inziens aannemelijk dat hierbij is beoogd om ook projecteigenaren uit te zonderen van de vergunningplicht voor kredietinstellingen indien deze partijen opvorderbare gelden aantrekken middels de uitgifte van obligaties en voor eigen rekening krediet uitzetten. ${ }^{75}$ Beoogd lijkt te zijn dat als funding wordt aangetrokken middels het platform, de projecteigenaar vervolgens niet wordt aangemerkt als kredietinstelling in verband met het feit dat (daardoor) opvorderbare gelden van het publiek worden aangetrokken. De vorm waarin de opvorderbare gelden worden aangetrokken, lijkt gelet op deze gedachte dan niet relevant.

De Crowdfundingverordening bepaalt eveneens dat als door de projecteigenaar via het crowdfundingplatform opvorderbare gelden worden aangetrokken daar geen vergunning, vrijstelling of ontheffing voor wordt vereist. ${ }^{76}$ Ook hierbij van beroep of bedrijf, maar mijn inschatting is dat dit zich in de praktijk niet veel zal voordoen. Overweging 9 en art. 1 lid 3 Crowdfundingverordening.

75 Een 'lening' is in de verordening gedefinieerd als: 'een overeenkomst waarbij een belegger gedurende een overeengekomen termijn een overeengekomen geldbedrag ter beschikking stelt aan een projecteigenaar en waarbij de projecteigenaar een onvoorwaardelijke verplichting aangaat om dat bedrag samen met de opgebouwde rente volgens het termijnbetalingsschema aan de belegger terug te betalen'. Een obligatie kan wellicht voor deze doeleinden ook onder deze definitie worden geschaard, hoewel een obligatie (eveneens) valt onder de definitie van effect zoals opgenomen in de verordening (art. 4 lid 1 punt 44 Richtlijn 2014/65/EU).

Overweging 9 en art. 1 lid 3 Crowdfundingverordening. 
wordt gerefereerd aan door de crowdfundingdienstverlener gefaciliteerde leningen.

Voor de projecteigenaar in Nederland die middels een crowdfundingdienstverlener een lening aantrekt, geldt dat die activiteit dan niet valt onder het verbod om in Nederland in de uitoefening van een bedrijf van het publiek opvorderbare gelden aan te trekken, ter beschikking te verkrijgen of ter beschikking te hebben. ${ }^{77}$ Het is wel mogelijk dat de projecteigenaar toch een vergunning nodig heeft. Dit zou bijvoorbeeld het geval kunnen zijn als de projecteigenaar consumentenkrediet verstrekt. Mijns inziens valt dit niet onder de in de verordening opgenomen uitzondering voor kredietinstellingen. Dit past namelijk niet goed bij de consumentenbeschermende gedachte van deze vergunningplicht en het Europees kader dat hiervoor is gecreëerd. Daarnaast geldt dat niet uitgesloten is dat als een projecteigenaar kwalificeert als een beleggingsinstelling, hiervoor een vergunning of registratieplicht van toepassing is. ${ }^{78}$ Dit zal zich wellicht overigens niet vaak voordoen omdat funding via crowdfunding in beginsel zal plaatsvinden ten behoeve van eigen, actieve bedrijfswerkzaamheden en niet om een (meer passieve) investering te doen.

\subsection{Informatieverplichtingen voor de projecteigenaar}

De Crowdfundingverordening reguleert en harmoniseert voor een deel de informatieverplichtingen die voor projecteigenaren gelden. Een belangrijke verplichting die geldt voor de projecteigenaar in verband met de informatie die de (poten-

77 Art. 3:5 Wft (conform art. 9 Richtlijn 2013/36). Omdat dit verbod in Nederland op dit moment in beginsel wel geldt, moet hiervoor (op dit moment nog) een wijziging plaatsvinden in de wetgeving, bijv. door een aanpassing van de Vrijstellingsregeling Wft. Partijen die middels een crowdfundingdienstverlener met een vergunning op grond van de verordening opvorderbare gelden aantrekken in de vorm van leningen (binnen het toepassingsbereik van de verordening, waaronder dat het - totale - bedrag niet meer is dan $€ 5$ miljoen) moeten zijn vrijgesteld (of op een andere manier uitgezonderd) van dit verbod. Voor partijen die effecten uitgeven op grond van de verordening geldt al een uitzondering op grond van art. 3:5 Wft indien zij de effecten uitgeven in overeenstemming met de Prospectusverordening (2017/1129). Het huidige art. 24b Vrijstellingsregeling Wft omvat de uitzondering onder het huidige/oude regime, wat niet past voor projecteigenaren die onder de verordening vallen. Art. 24b Vrijstellingsregeling: 'Van artikel 3:5, eerste lid, van de wet zijn vrijgesteld personen die opvorderbare gelden aantrekken of ter beschikking verkrijgen door middel van een publiekslening als bedoeld in artikel 2a, tweede lid, van het besluit, alsmede personen die als gevolg van een zodanige aantrekking of verkrijging opvorderbare gelden ter beschikking hebben, mits:

a zij van het aantrekken of ter beschikking verkrijgen van de opvorderbare gelden niet hun bedrijf maken;

b het aantrekken of ter beschikking verkrijgen van de opvorderbare gelden niet geschiedt met het oogmerk om kredieten te verlenen;

c het aantrekken of ter beschikking verkrijgen van de opvorderbare gelden geschiedt door tussenkomst van een persoon die over een ontheffing beschikt als bedoeld in artikel 4:3, vierde lid, van de wet; en

d het totale bedrag aan opvorderbare gelden dat per publiekslening door de persoon, bedoeld in de aanhef, over een periode van 12 maanden wordt aangetrokken of ter beschikking wordt verkregen ten hoogste $€ 2,5$ miljoen bedraagt.' 
tiële) investeerders ontvangen, is de verplichting om het (standaard) essentiële informatieblad op te stellen. ${ }^{79}$ Dit informatiedocument wordt opgesteld in overeenstemming met bijlage 1 bij de Crowdfundingverordening. Het is ook voor de hand liggend dat de verplichting tot het opstellen van dit document geldt voor de projecteigenaar, omdat deze het beste in staat is om die informatie te verzamelen. In dit document wordt onder meer informatie opgenomen over de projecteigenaar en over het crowdfundingproject. Het informatieblad bevat ook enkele vaste teksten, waaronder een disclaimer en een risicowaarschuwing. ${ }^{80} \mathrm{Er}$ zal overigens ook een verantwoordelijkheidsverklaring in het informatieblad moeten worden opgenomen door de projecteigenaar. ${ }^{81}$ Als er wijzigingen zijn in de informatie, zal de projecteigenaar dit dienen te communiceren aan de crowdfundingdienstverlener, zodat de dienstverlener dit vervolgens weer kan communiceren met de investeerders.

Projecteigenaren die effecten uitgeven via een crowdfundingplatform dat onder de verordening valt, hebben onder voorwaarden geen (goedgekeurd) prospectus op grond van de Prospectusverordening nodig. ${ }^{82}$ De crowdfundingaanbiedingen zullen in dat geval niet meer bedragen dan $€ 5$ miljoen, berekend over een periode van twaalf maanden. Het betreft hierbij wel een bedrag op basis van alle aanbiedingen die via een crowdfundingplatform door de projecteigenaar zijn gedaan, dus zowel voor wat betreft effecten als voor wat betreft leningen. ${ }^{83} \mathrm{Om}$ dit te bereiken is een uitzondering gecreëerd in de Prospectusverordening. ${ }^{84}$ Een voordeel hiervan is dat de vrijstelling van de prospectusplicht op gelijke wijze geldt in de verschillende lidstaten.

Er gelden voor de projecteigenaar uiteraard nog steeds informatieverplichtingen zoals het opstellen van het genoemde informatieblad. De verordening heeft er wel in geresulteerd dat diverse verplichtingen ten opzichte van de investeerders worden verschoven en voornamelijk gelden tussen de projecteigenaar en de crowdfundingdienstverlener. De crowdfundingdienstverlener moet er vervolgens voor zorgen dat de (potentiële) investeerders de benodigde informatie (tijdig)

79 Art. 23 Crowdfundingverordening. Als de crowdfundingdienstverlener voorziet in individueel portefeuillebeheer van leningen, zijn de eisen die gelden voor de dienstverlener en de projecteigenaar anders en gelden eisen op platformniveau (art. 24 Crowdfundingverordening).

80 Art. 23 lid 6 Crowdfundingverordening.

81 Art. 23 lid 9 en bijlage 1 bij de Crowdfundingverordening. Deze verklaring is soortgelijk aan de verklaring die moet worden afgegeven in het kader van het publiceren van een goedgekeurd prospectus. Interessant is om te zien of op termijn daarmee ook een soortgelijke (interpretatie van) aansprakelijkheid zal gaan gelden.

82 Er is overigens geen uitzondering gecreëerd voor de prospectusplicht op basis van Richtlijn 2011/61 voor beleggingsinstellingen.

83 Het combineren met andere aanbiedingen van effecten (niet via een crowdfundingplatform dat onder de verordening valt) lijkt wel nog steeds mogelijk.

84 Art. 1 lid 4 Prospectusverordening (zoals gewijzigd op basis van art. 46 Crowdfundingverordening). Hoewel wordt verwezen naar een uitzondering van de prospectusplicht voor een crowdfundingdienstverlener, ligt het voor de hand dat dezelfde uitzondering geldt voor de aanbieding door de projecteigenaar, omdat anders het doel van de uitzondering feitelijk niet zou worden bereikt. Dit lijkt ook te volgen uit overweging 16 en 17 en art. 1 lid 2 sub c Crowdfundingverordening. 
ontvangen. De crowdfundingdienstverlener gaat in dit verband dus fungeren als een aangewezen tussenschakel.

\section{$7 \quad$ Conclusie}

De Crowdfundingverordening heeft een aanzienlijke impact op crowdfundingdienstverleners en projecteigenaren. De crowdfundingdienstverleners hebben een vergunning nodig waar diverse eisen aan verbonden zijn. Hierbij is voor bestaande partijen van belang dat die eisen slechts ten dele overeenkomen met de vergunnings- en ontheffingsvereisten die in Nederland gelden voorafgaand aan de vergunningsverplichting op grond van de verordening.

Positief is uiteraard het paspoort voor de crowdfundingdienstverleners, zodat zij - net zoals veel andere financiële ondernemingen - op basis van de verkregen vergunning ook in andere lidstaten de crowdfundingdiensten kunnen aanbieden. Ook zal de verordening resulteren in meer eenheid in de informatieverplichtingen en daarmee in de informatieverstrekking richting investeerders door platformen in de Europese Unie. De verplichtingen en verantwoordelijkheden die zij hebben in verband met de aanbiedingen die via het platform worden gedaan, lijken op basis van de teksten van de verordening iets toe te nemen. Interessant zal zijn om te zien hoe (de verdeling van) de verantwoordelijkheden er in de praktijk uit (zal) zullen komen te zien.

Voor de projecteigenaren die funding wensen te verkrijgen via de (vergunninghoudende) platformen, lijkt de Crowdfundingverordening meer uniformiteit te creëren in de informatieverplichtingen in de verschillende lidstaten. Omdat het crowdfundingplatform - ook juridisch en formeel - meer zal gaan functioneren als een tussenschakel in de informatieverplichtingen naar de (potentiële) investeerders, lijkt daar potentieel meer afhankelijkheid van het platform te bestaan. Dit kan, in combinatie met de verantwoordelijkheidsverklaring van de projecteigenaar in het standaardinformatieblad, mogelijk in de toekomst tot juridische vraagstukken leiden en resulteren in juridische onzekerheden over de verantwoordelijkheidsverdeling ten opzichte van de investeerders. 